\title{
Chemical Composition and Source Characterization of Hailstones in Dhaka, Bangladesh
}

\author{
Rasheda Aktar Samiha1, Morshad Ahmed1, Mohammad Shohel1,2, Abdus Salam* \\ ${ }^{1}$ Department of Chemistry, Faculty of Science, University of Dhaka, Dhaka, Bangladesh \\ ${ }^{2}$ Department of Chemistry, University of Iowa, Iowa City, IA, USA \\ Email: ^asalam@gmail.com
}

How to cite this paper: Samiha, R.A., Ahmed, M., Shohel, M. and Salam, A. (2018) Chemical Composition and Source Characterization of Hailstones in Dhaka, Bangladesh. Journal of Geoscience and Environment Protection, 6, 71-82. https://doi.org/10.4236/gep.2018.69006

Received: July 20, 2018

Accepted: September 2, 2018

Published: September 5, 2018

Copyright $\odot 2018$ by authors and Scientific Research Publishing Inc. This work is licensed under the Creative Commons Attribution International License (CC BY 4.0).

http://creativecommons.org/licenses/by/4.0/

\begin{abstract}
A comprehensive analysis on the chemical composition and source apportionment of hailstone samples were conducted in Dhaka, Bangladesh. $\mathrm{pH}$, electrical conductivity (EC), total dissolved solids (TDS), water soluble ions $\left(\mathrm{Na}^{+}, \mathrm{K}^{+}, \mathrm{Ca}^{2+}, \mathrm{Mg}^{2+}, \mathrm{Cl}^{-}, \mathrm{SO}_{4}^{2-}, \mathrm{NO}_{3}^{-}, \mathrm{HCO}_{3}^{-}\right)$and trace metals $(\mathrm{Zn}, \mathrm{Fe}$, $\mathrm{Cu}, \mathrm{Mn}$ ) of hailstone were determined. The result revealed that the average $\mathrm{pH}, \mathrm{EC}$, TDS were $6.95 \pm 0.54,356.3 \pm 150.6 \mu \mathrm{S} \cdot \mathrm{cm}^{-1}$ and $17.5 \pm 2.89 \mathrm{mg} \cdot \mathrm{L}^{-1}$, respectively. The water soluble ions followed the order: $\mathrm{Ca}^{2+}>\mathrm{Cl}^{-}>\mathrm{SO}_{4}^{2-}>$ $\mathrm{HCO}_{3}^{-}>\mathrm{Na}^{+}>\mathrm{Mg}^{2+}>\mathrm{K}^{+}>\mathrm{NO}_{3}^{-}$. The concentrations of trace metals ranged in order with $\mathrm{Zn}>\mathrm{Fe}>\mathrm{Cu}$, while the concentration of $\mathrm{Mn}$ was below detection limit. Sodium adsorption ratio (SAR) was $0.20 \pm 0.09 \mathrm{meqL}^{-1}$ which indicates it is benign to plants and safe for irrigation. The order of neutralization factor (calculated with average concentrations) found in hailstone was $\mathrm{NF}_{\mathrm{Ca}}(1.16)>\mathrm{NF}_{\mathrm{Mg}}(0.36)>\mathrm{NF}_{\mathrm{K}}(0.32)$ which were originated from earth crust. Notable correlation was found in between soil tracers $\mathrm{Ca}^{2+}$ and $\mathrm{Mg}^{2+}(\mathrm{r}=$ 0.87), indicating their common source dust. Enrichment factor analysis revealed that $\mathrm{Ca}^{2+}, \mathrm{Mg}^{2+}$ and $\mathrm{K}^{+}$are mainly from crust, whereas $\mathrm{NO}_{3}^{-}$and $\mathrm{SO}_{4}^{2-}$ are mainly attributable to anthropogenic origins. Further source contribution analysis revealed that anthropogenic actions accounted for $99.2 \%$ of total $\mathrm{NO}_{3}{ }^{-}$and $89.6 \%$ of total $\mathrm{SO}_{4}^{2-}$, while $99.2 \%$ of total $\mathrm{Ca}^{2+}$ and $95 \% \mathrm{Mg}^{2+}$ were from crustal source.
\end{abstract}

\section{Keywords}

Hailstone, Water Soluble Ion, Trace Metal, Source Apportionment

\section{Introduction}

Hailstones are lumps of ice, which are deposited in the atmosphere by complex 
heterogeneous nucleation mechanisms at a below average atmospheric temperature [1]. According to radar observations, in large areas of Switzerland hail takes place on average once per convective season per $\mathrm{km}^{2}$ [2]. But the internal Alpine valleys show an exceptional appearance [2]. Radar-based hail detection is beneficial because of the near-continuous exploration of the region, the near-real-time accessibility of data, and good parallel spatial conclusion (at least near the radar station) [3]. The signal of hail movements can vary greatly in adjacent areas [4] and their intensity depends on the reviewed time period [5]. In Europe, usually large hail is detected in environments characterized by high border layer moisture, a high raising condensation level and vertical lapse rates [6], and by mixture of high-CAPE (convective available potential energy) moderate-shear or moderate-CAPE high-shear atmosphere [7]. Formation of hailstorms depends on three main ingredients: an inconsistent atmosphere, lower tropospheric humidity and a lifting process, i.e. Thunderstorm trigger [8]. Relative significance of these components depends on regional elements, such as terrain barriers, thermotopographic wind systems, or warm water surfaces [9]. Severe hailstorms regularly cause damage to buildings, automobiles, crops in a large extent and resulting in huge economic and assured losses [10]. Determining the composition of hailstone may provide valuable documentation on the relative contribution of different origins of pollutants to hailstone chemistry and enhance comprehension of the local and regional diffusion of pollutants. But knowledge on chemical composition and their source apportionment in hail is still limited. Previous experiments with hail in developed nations (EU, USA, Canada) have given information only about climatology, size distribution, and suppression of hailstones. Santoyo et al., 2002 provide information only about the concentration of anions found in hailstones [1]. There is also lack of research on how atmospheric pollution control the chemistry of hail. Our recent study has revealed that polluted air mass can cause enrichment of anthropogenic species in dew water and fog water at Indo-gangetic plain (IGP), which comprise of India, Pakistan, Nepal and Bangladesh [11] [16] [32]. So we decided to study the physiochemical properties and sources of chemical species present in hailstones at one of the major city of IGP (Dhaka, Bangladesh).

In the present work, we have collected hailstone samples on February, 2016 in Dhaka, capital of Bangladesh. We have studied different physical properties $(\mathrm{pH}$, electrical conductivity and total dissolved solid) and measure the concentration of water soluble ions and trace metals. The sources of chemical species present in hailstones were characterized by enrichment factor, correlation co-efficient and percent source contribution calculation.

\section{Materials and Methods}

\subsection{Experimental Site}

Hailstone samples were collected from Dhaka (longitude $90^{\circ} 23^{\prime} 52^{\prime \prime} \mathrm{E}$ and latitude $23^{\circ} 43^{\prime} 40^{\prime \prime} \mathrm{N}$ ), the capital of Bangladesh. Dhaka is one of the most heavily popu- 
lated city in the world accompanied by 15 million people [12]. The environment of Dhaka can be contaminated from particular types of regional or long-range anthropogenic sources [13]. It has experienced with unrestrained growth and few managing restraints, resulting in vigorous traffic blockage with a mix of transport medium such as cars, buses, trucks, bicycle rickshaws, bay-taxis, and all struggles for coexistence on the roadways. Due to the abundance and mismanagement of emission sources, atmospheric condition of Dhaka is getting worse day by day.

\subsection{Meteorology of Dhaka, Bangladesh}

The climate of Bangladesh is described by high temperature, excessive humidity, and clearly noticeable seasonal dissimilarities in precipitation [14]. The weather of Bangladesh is divided into four seasons: pre-monsoon (March-May), monsoon (June-September), post-monsoon (October-November), and winter (December-February) [14]. In this study, hailstones were collected during the winter season.

\subsection{Sampling Procedure and Handling}

A severe hailstorm occurred in 24th February, 2016 at the Dhaka University area. Dhaka University has an urban campus and located in the southern part of Dhaka metropolitan area. It is one of the busiest spots of Dhaka city and congested with traffic, shopping outlet, street food shop and restaurant. We put aluminum foil on five different locations around the campus. As soon as hailstones dropped on the aluminum foil, they were collected using gloves. Hailstones samples of four representative events were collected at four different locations in the University of Dhaka (Figure 1). Hailstones were rinsed with de-ionized water before storing them in clean PET (Polyethylene terephthalate) bottles. The samples were immediately preserved in refrigeration to avoid reduction of substance by vaporization and also to prevent pollution.

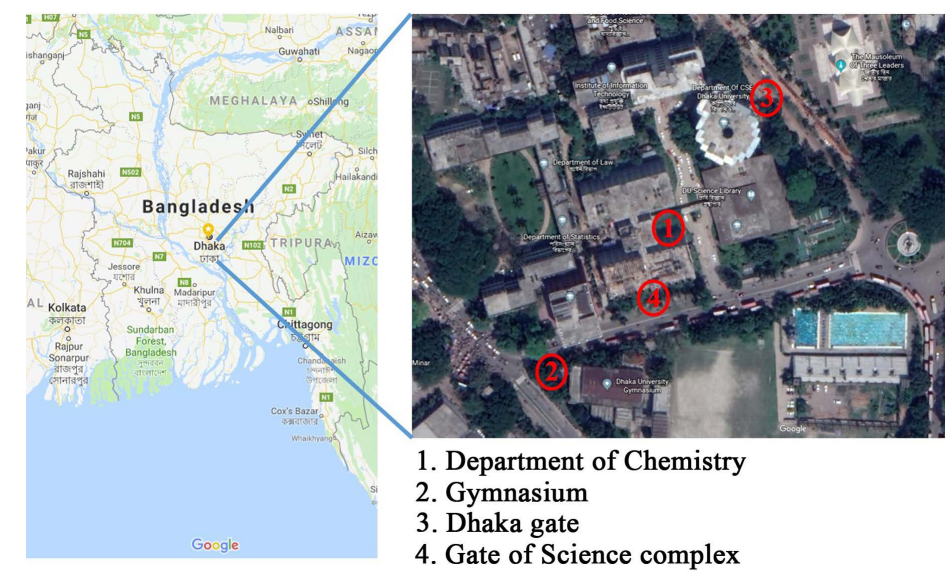

Figure 1. Map of Bangladesh (left) and sampling locations at Dhaka university area (right). 


\subsection{Analytical Procedure}

The hailstone samples were first divided into two parts. One part was used for measuring $\mathrm{pH}, \mathrm{EC}$ and TDS. The other part of each sample was used to determine concentration of water soluble ions and trace metals. $\mathrm{pH}$, EC and TDS were measured by a $\mathrm{pH}$ meter ( $\mathrm{pH} 211$, Hanna Instruments), conductivity meter (CM-5S, DKK-TOA Corporation) and TDS meter (hold), respectively. Another part of the sample was divided into two for trace metals and water soluble ions analysis. One part of the sample was mixed with $0.2 \%$ nitric acid $(1 \% \mathrm{~V} / \mathrm{V})$ and kept alone. Concentration of water soluble cations $\left(\mathrm{Na}^{+}, \mathrm{K}^{+}, \mathrm{Ca}^{2+}, \mathrm{Mg}^{2+}\right)$ and trace metals $(\mathrm{Fe}, \mathrm{Zn}, \mathrm{Cu}, \mathrm{Mn})$ were measured by flame atomic absorption spectrophotometer (model: A Analyst 800, Perkin Elmer). Concentrations of water-soluble anions $\left(\mathrm{Cl}^{-}, \mathrm{SO}_{4}^{2-}, \mathrm{NO}_{3}^{-}\right)$were determined by ion chromatography (model: 881 compact, IC pro, Metrohm, Germany). Sample blank was prepared using the chemicals used for analysis (without sample) and analyzed using the same procedure. Concentration of different ions from blanks was subtracted from the sample to ignore contamination error in the measurement. Concentration of $\mathrm{HCO}_{3}^{-}$was evaluated as follows from $\mathrm{pH}[11]$ :

$$
\left[\mathrm{HCO}_{3}^{-}\right]=10^{-11.2+\mathrm{pH}}
$$

\section{Results and Discussion}

\section{1. $\mathrm{pH}, \mathrm{EC}$ and TDS}

The melted hail samples were examined for EC, $\mathrm{pH}$ and TDS and the results were summarized in table 1. $\mathrm{pH}$ values ranged from 6.16 to 7.08 with an average value of $6.95 \pm 0.54$, which is almost neutral. It must be highlighted that the acidity of hailstone was mainly neutralized by soil derived basic compound. The average value of EC was $70.5 \pm 65.9 \mu \mathrm{S} \cdot \mathrm{cm}^{-1}$ varied from $155 \mu \mathrm{S} \cdot \mathrm{cm}^{-1}$ to 37 $\mu \mathrm{S} \cdot \mathrm{cm}^{-1}$. Average TDS value was $17.5 \pm 2.89 \mathrm{mg} \cdot \mathrm{L}^{-1}$ varied from $15 \mathrm{mg} \cdot \mathrm{L}^{-1}$ to 20 $\mathrm{mg} \cdot \mathrm{L}^{-1}$. We compared our measured EC, $\mathrm{pH}$ and TDS with rain, fog and dew water in Table 1 . The average $\mathrm{pH}$ was found higher than rain and dew water. Average EC and TDS were found lower than fog and dew water.

\subsection{Chemical Composition}

The average concentration of cations $\left(\mathrm{Ca}^{2+}, \mathrm{Na}^{+}, \mathrm{Mg}^{2+}, \mathrm{K}^{+}\right)$, anions $\left(\mathrm{Cl}^{-}, \mathrm{SO}_{4}^{2-}\right.$, $\mathrm{NO}_{3}^{-}, \mathrm{HCO}_{3}^{-}$) and trace metals $(\mathrm{Zn}, \mathrm{Fe}, \mathrm{Cu}, \mathrm{Mn})$ for hailstone in Dhaka and comparison with rain, fog and dew water in Bangladesh were summarized in Table 1. The ion concentrations show higher as well as lower dispersion around their average values according to the standard deviations. The average concentration of $\mathrm{Ca}^{2+}, \mathrm{Na}^{+}, \mathrm{Mg}^{2+}$ and $\mathrm{K}^{+}$were recorded as $163.4 \pm 81.9,56.9 \pm 16.2,50.3$ \pm 19.3 and $44.5 \pm 7.78 \mu \mathrm{eq} \cdot \mathrm{L}^{-1}$, with maxima of $212.5,80.4,69.1$ and 50.1 $\mu \mathrm{eq} \cdot \mathrm{L}^{-1}$, with minima of $40.9,43.9,26.3$ and $32.9 \mu \mathrm{eq} \cdot \mathrm{L}^{-1}$, respectively. Average concentration of $\mathrm{Mg}^{2+}$ and $\mathrm{Ca}^{2+}$ were higher in hailstones than rain water in Dhaka but lower than dew and fog water in Bhola. Similarly, $\mathrm{Na}^{+}$and $\mathrm{K}^{+}$ 
Table 1. Comparison of the chemical composition of Hailstones with Rain, Dew, Fog water samples collected from Bangladesh. All units in $\mu$ eq $\cdot \mathrm{L}^{-1}$, except-pH, TDS and LOD are in $\mathrm{mg} \cdot \mathrm{L}^{-1}$, EC in $\mu \mathrm{S} \cdot \mathrm{cm}^{-1}$.

\begin{tabular}{ccccc}
\hline Variables & $\begin{array}{c}\text { Hailstone } \\
\text { Dhaka }\end{array}$ & $\begin{array}{c}\text { Rain water } \\
\text { Dhaka }\end{array}$ & $\begin{array}{c}\text { Fog water } \\
\text { Bhola }\end{array}$ & $\begin{array}{c}\text { Dew water } \\
\text { Bhola }\end{array}$ \\
\hline $\mathrm{pH}$ & $6.95 \pm 0.54$ & $6.40 \pm 0.16$ & $7.13 \pm 0.40$ & $6.81 \pm 0.20$ \\
$\mathrm{EC}$ & $70.5 \pm 65.9$ & $20.9 \pm 8.85$ & $346.9 \pm 66.9$ & $155 \pm 62$ \\
$\mathrm{TDS}$ & $17.5 \pm 2.89$ & $6.40 \pm 4.14$ & $235.7 \pm 156.9$ & NA \\
$\mathrm{Ca}^{2+}$ & $163.4 \pm 81.9$ & $47.4 \pm 21.5$ & $780 \pm 398.2$ & $693.3 \pm 361.3$ \\
$\mathrm{Na}^{+}$ & $56.9 \pm 16.2$ & $26.1 \pm 14.9$ & $705 \pm 376.4$ & $243.8 \pm 126.7$ \\
$\mathrm{Mg}^{2+}$ & $50.3 \pm 19.3$ & $9.30 \pm 2.65$ & $240 \pm 194.9$ & $205.1 \pm 188.3$ \\
$\mathrm{~K}^{+}$ & $44.5 \pm 7.78$ & $7.10 \pm 0.98$ & $310 \pm 110.5$ & $135.6 \pm 45.7$ \\
$\mathrm{Zn}^{+}$ & $9.71 \pm 3.80$ & $4.30 \pm 0.56$ & $20.8 \pm 0.87$ & $10.7 \pm 0.28$ \\
$\mathrm{Fe}$ & $2.95 \pm 0.77$ & $\mathrm{BDL}(\mathrm{LOD}=0.04)$ & $7.88 \pm 0.32$ & $10.03 \pm 0.73$ \\
$\mathrm{Cu}^{+}$ & $0.94 \pm 0.30$ & $\mathrm{BDL}(\mathrm{LOD}=0.03)$ & $4.41 \pm 0.71$ & $2.52 \pm 0.58$ \\
$\mathrm{Mn}^{\mathrm{B}}$ & $\mathrm{BDL}(\mathrm{LOD}=0.02)$ & $\mathrm{BDL}(\mathrm{LOD}=0.02)$ & $7.64 \pm 1.54$ & $6.92 \pm 0.47$ \\
$\mathrm{Cl}^{-}$ & $30.4 \pm 11.5$ & $16.1 \pm 6.54$ & $860 \pm 293.7$ & $291.2 \pm 127.7$ \\
$\mathrm{SO}_{4}^{2-}$ & $97.3 \pm 34.1$ & $11.4 \pm 2.11$ & $480 \pm 137.3$ & $264.1 \pm 135.2$ \\
$\mathrm{NO}_{3}^{-}$ & $43.7 \pm 27.5$ & $41.4 \pm 22.8$ & $220 \pm 93.5$ & $223.2 \pm 131.9$ \\
$\mathrm{HCO}_{3}^{-}$ & $80.6 \pm 60.1$ & $47.1 \pm 25.5$ & $110 \pm 54.8$ & $63.0 \pm 22.3$ \\
\hline
\end{tabular}

$\mathrm{BDL}=$ below detection limit; $\mathrm{LOD}=$ limit of detection; NA = Not analyzed. a. Afser, 2018 [15]; b. Ahmed et al., 2018 [16], Akter, 2018 [32]; c. Shohel et al., 2017 [11].

concentration in hailstone samples were higher than rain water but much lower than fog and dew water. Trace metals, including $\mathrm{Fe}, \mathrm{Cu}, \mathrm{Zn}$ and $\mathrm{Mn}$ were analyzed in hailstone samples. $\mathrm{Zn}, \mathrm{Fe}$ and $\mathrm{Cu}$ were found with an average value of $9.71 \pm 3.8,2.95 \pm 0.77$ and $0.94 \pm 0.30 \mu \mathrm{eq} \cdot \mathrm{L}^{-1}$, respectively. Average $\mathrm{Zn}$ concentration was relatively higher in hailstones, rain and fog than any other trace metals. In terms of water soluble anions, $\mathrm{Cl}^{-}, \mathrm{SO}_{4}^{2-}, \mathrm{NO}_{3}^{-}, \mathrm{HCO}_{3}^{-}$were found with an average concentration of $30.4 \pm 11.5,97.3 \pm 34.1,43.7 \pm 27.5$ and $80.6 \pm$ $60.1 \mu \mathrm{eq} \cdot \mathrm{L}^{-1}$, with maxima of $43.2,128.8,76.6$ and $154.9 \mu \mathrm{eq} \cdot \mathrm{L}^{-1}$, with minima of $17.85,49.4,14.5$ and $9.12 \mu \mathrm{eq} \cdot \mathrm{L}^{-1}$, respectively. The average anionic concentrations were much higher than rainwater in Dhaka but lower than the value in fog water and dew water in Bhola.

From handful studies in the literature, in detail chemical composition of hailstone was only found for five provinces in Spain [1]. The average concentration of $\mathrm{Cl}^{-}$ion was lower in Dhaka comparable to five provinces of Spain. Average concentration of $\mathrm{NO}_{3}^{-}$was lower than Algemesi and Enguera, but higher than the other three sites (Chilches, Alcudia, Tosina) of Spain. Average $\mathrm{SO}_{4}^{2-}$ concentration was lower in Dhaka than the provinces of Spain except Alcudia. The formation of $\mathrm{H}_{2} \mathrm{SO}_{4}$ and $\mathrm{HNO}_{3}$ could be from the complex reaction of predeces- 
sor gases $\mathrm{SO}_{2}$ and $\mathrm{NO}_{\mathrm{x}}$ that were liberated into the environment by industry, traffic brick kilns and agricultural activities [17].

\subsection{Sodium Adsorption Ratio (SAR)}

The SAR value is noted as a water quality parameter for irrigation. From the following equation SAR is calculated:

$$
\mathrm{SAR}=\mathrm{Na}^{+} / \sqrt{\left(\mathrm{Ca}^{2+}+\mathrm{Mg}^{2+}\right) / 2}
$$

Here, $\mathrm{Ca}^{2+}, \mathrm{Na}^{+}$and $\mathrm{Mg}^{2+}$ were calculated in meq $\cdot \mathrm{L}^{-1}$ of calcium, sodium and magnesium ions, respectively [18].

FAO (1985) suggests that water having SAR value less than 3.0 is acceptable for irrigation [19]. Average SAR value for hailstone was $0.20 \pm 0.09 \mathrm{meq} \cdot \mathrm{L}^{-1} \mathrm{va}$ ried from $0.31 \mathrm{meq} \cdot \mathrm{L}^{-1}$ to $0.11 \mathrm{meq} \cdot \mathrm{L}^{-1}$. Average $\mathrm{SAR}$ value for rain, fog, dew water were $0.12 \pm 0.03,0.99 \pm 0.58,0.20 \pm 0.34 \mathrm{meq} \cdot \mathrm{L}^{-1}$, respectively. This result indicates that all the samples were benign to plants and safe for irrigation.

\subsection{Fractional Acidity}

Fractional acidity of hailstone was computed using the following formula [11] [20].

$$
\mathrm{FA}=\frac{\left[\mathrm{H}^{+}\right]}{\left[\mathrm{SO}_{4}^{2-}\right]+\left[\mathrm{NO}_{3}^{-}\right]}
$$

When FA is 1 , it is supposed to be not neutralized. 0.002 was the average value of FA (highest 0.007 , lowest 0.0004 ), recommended influential neutralization of acidic substances $\left(\mathrm{NO}_{3}^{-}, \mathrm{SO}_{4}^{2-}\right.$, etc.) by basic substances $\left(\mathrm{NH}_{4}^{+}, \mathrm{Ca}^{2+}, \mathrm{Mg}^{2+}, \mathrm{K}^{+}\right)$. The relative contributions of $\mathrm{SO}_{4}^{2-}$ and $\mathrm{NO}_{3}^{-}$towards acidification were calculated using the formulas:

$$
\mathrm{C}\left(\mathrm{SO}_{4}^{2-}\right)=\left(\left[\mathrm{SO}_{4}^{2-}\right] /\left[\mathrm{SO}_{4}^{2-}+\mathrm{NO}_{3}^{-}\right]\right)
$$

and

$$
\mathrm{C}\left(\mathrm{NO}_{3}^{-}\right)=\left(\left[\mathrm{NO}_{3}^{-}\right] /\left[\mathrm{SO}_{4}^{2-}+\mathrm{NO}_{3}^{-}\right]\right)
$$

respectively [21]. The contribution of $\mathrm{H}_{2} \mathrm{SO}_{4}$ to acidity varied between $47.47 \%$ $89.87 \%$ (average $77.16 \%$ ) and the contribution of $\mathrm{HNO}_{3}$ to acidity varied between $10.13 \%-52.53 \%$ (average $31.50 \%$ ).

\subsection{Neutralization Factor}

By determining the neutralization factor, contribution of basic substances to the neutralization procedure is determined, via the equation [22]:

$$
\mathrm{NF}_{\mathrm{x}}=\frac{[\mathrm{X}]}{\left[\mathrm{NO}_{3}^{-}\right]+\left[\mathrm{SO}_{4}^{2-}\right]}
$$

Here, neutralization factor of $\mathrm{X}$ is to be determined. The order of neutraliza- 
tion factor (calculated with average concentration) found in hailstone of Dhaka was $\mathrm{NF}_{\mathrm{Ca}}(1.16)>\mathrm{NF}_{\mathrm{Mg}}(0.36)>\mathrm{NF}_{\mathrm{K}}(0.32)$.

\subsection{Enrichment Factors}

The enrichment factors (EFs) for individual ions were used to identify their origin in hailstone as general crust, sea salt and anthropogenic source. Na is considered as a reference element for marine sources. $\mathrm{Ca}$ is used as reference element for soil origin [23]. For continental crust, $\mathrm{Fe}, \mathrm{Al}$ and $\mathrm{Ca}$ are standard lithophilic elements used as reference elements [21]. $\mathrm{EF}_{\text {seawater }}$ and $\mathrm{EF}_{\text {crust }}$ of major cations and anions were determined by the following calculation, taking $\mathrm{Na}$ and $\mathrm{Ca}$ as reference elements [24]:

$$
\begin{aligned}
\mathrm{EF}_{\text {seawater }} & =(\mathrm{X} / \mathrm{Na})_{\text {hail }} /(\mathrm{X} / \mathrm{Na})_{\text {sea }} \\
\mathrm{EF}_{\text {crust }} & =(\mathrm{X} / \mathrm{Na})_{\text {hail }} /(\mathrm{X} / \mathrm{Na})_{\text {soil }}
\end{aligned}
$$

Here, $X$ is the concentration of individual element. $(\mathrm{X} / \mathrm{Na})_{\text {sea }}$ is the ratio of elemental concentration to the $\mathrm{Na}$ concentration from seawater composition [25], and $(\mathrm{X} / \mathrm{Ca})_{\text {crust }}$ is the ratio of the elemental concentration to the Ca concentration from crustal composition [26]. An EF value much less than or much higher than 1 is considered to be diluted or enriched respectively relative to the reference source [27].

The EF of major ions of hailstone samples collected at Dhaka is shown in Table 2. $\mathrm{Cl}^{-}$has an average $\mathrm{EF}_{\text {crust }}$ value of $0.48 \pm 0.18$ indicating its anthropogenic source. Further, average $\mathrm{EF}_{\text {crust }}$ and $\mathrm{EF}_{\text {seawater }}$ value of $\mathrm{K}^{+}$and $\mathrm{Mg}^{+}$suggested it crustal origin with a small amount of marine origin. The smaller $\mathrm{EF}_{\text {crust }}$ and EFseawater value of $\mathrm{K}^{+}$indicated primarily crustal source, with preferential contribution from sea sources [24]. $\mathrm{NO}_{3}^{-}$is enriched comparable to crust source (average $\mathrm{EF}=167.9 \pm 127.3)$ and sea source (average $\mathrm{EF}=44000 \pm 31777.9)$ which suggested the contribution of $\mathrm{NO}_{3}^{-}$from mainly anthropogenic source. Relatively small average $\mathrm{EF}_{\text {seawater }}$ value of $\mathrm{SO}_{4}^{2-}$ indicates a small portion of $\mathrm{SO}_{4}^{2-}$ was from marine source. Again, relatively high $\mathrm{EF}_{\text {crust }}$ value of $\mathrm{SO}_{4}^{2-}$ suggests that the main sources of $\mathrm{SO}_{4}^{2-}$ are anthropogenic activities.

Table 2. $\mathrm{EF}_{\text {sea water }}$ and $\mathrm{EF}_{\text {crust }}$ of different chemical species present in hailstones in Dhaka, Bangladesh.

\begin{tabular}{ccc}
\hline Elements & $\mathrm{EF}_{\text {seawater }}$ & $\mathrm{EF}_{\text {crust }}$ \\
\hline $\mathrm{K}^{+}$ & $3.59 \pm 1.13$ & $0.86 \pm 0.87$ \\
$\mathrm{Ca}^{2+}$ & $139.7 \pm 83.5$ & 1 \\
$\mathrm{Mg}^{2+}$ & $21.9 \pm 11.9$ & $0.66 \pm 0.33$ \\
$\mathrm{Cl}^{-}$ & $0.48 \pm 0.18$ & $76.6 \pm 45.9$ \\
$\mathrm{NO}_{3}^{-}$ & $44,000 \pm 31,777.9$ & $167.9 \pm 127.3$ \\
$\mathrm{SO}_{4}^{2-}$ & $13.7 \pm 3.79$ & $51.2 \pm 52.5$ \\
\hline
\end{tabular}




\subsection{Correlation Coefficient Analysis among Hailstone Chemical Species}

Correlation analysis was done with $r$ values $<0.01$ to investigate the association and likely common sources between the chemical species in hailstone samples [28]. It can be inferred that the correlation coefficient data set is statically small but still give useful information for the common sources of these elements (Table 3). Hence a strong correlation was found between soil tracers $\mathrm{Ca}^{2+}$ and $\mathrm{Mg}^{2+}(\mathrm{r}=0.87)$, suggesting a common source of these elements which was soil dust [29]. Further, correlation between $\left(\mathrm{Mg}^{2+}, \mathrm{NO}_{3}^{-}\right)$and $\left(\mathrm{Ca}^{2+}, \mathrm{Cl}^{-}\right)$were 0.81 and 0.67 , respectively was observed probably due to the interaction between the acids $\left(\mathrm{HNO}_{3}\right.$ and $\left.\mathrm{HCl}\right)$ with basic compounds $\left(\mathrm{Ca}^{2+}\right.$ and $\left.\mathrm{Mg}^{2+}\right)$ as they move to upper atmosphere from soil by air [30]. Similarly, a strong correlation was found for $\mathrm{Na}^{+}-\mathrm{SO}_{4}^{2-}(\mathrm{r}=0.75)$ pointed that some $\mathrm{SO}_{4}^{2-}$ originated from marine source [30]. Fe and $\mathrm{Zn}$ are strongly correlated $(r=0.99)$ with each other meaning they are coming from the same origin. Significant inconsistent and irregular correlation suggested that these elements were originated from different distinct local sources.

\subsection{Source Contributions for Different Ionic Species}

The marine, crustal and anthropogenic sources of ionic components in hailstone samples were calculated by using the following equation [30]:

$$
\begin{gathered}
\% \mathrm{SSF}=100(\mathrm{X} / \mathrm{Na})_{\text {sea }} /(\mathrm{X} / \mathrm{Na})_{\text {hail }} \\
\% \mathrm{CF}=100(\mathrm{X} / \mathrm{Na})_{\text {soil }} /(\mathrm{X} / \mathrm{Na})_{\text {hail }} \\
\% \mathrm{AF}=100-\% \mathrm{SSF}-\% \mathrm{CF}
\end{gathered}
$$

Here, $\mathrm{X}$ is the concentration of individual element. SSF, CF and AF represents the sea salt fraction, crustal fraction and anthropogenic fraction, respectively (Table 4).

Table 3. Correlation coefficient matrix for the chemical species in hailstone samples.

\begin{tabular}{cccccccccc}
\hline & $\mathrm{Cl}^{-}$ & $\mathrm{NO}_{3}^{-}$ & $\mathrm{SO}_{4}^{2-}$ & $\mathrm{Na}^{+}$ & $\mathrm{K}^{+}$ & $\mathrm{Ca}^{2+}$ & $\mathrm{Mg}^{2+}$ & $\mathrm{Zn}$ & $\mathrm{Fe}$ \\
\hline $\mathrm{Cl}^{-}$ & 1 & -0.35 & 0.00 & 0.55 & 0.24 & $0.67^{*}$ & 0.25 & -0.75 & -0.68 \\
$\mathrm{NO}_{3}^{-}$ & & 1 & -0.356 & -0.78 & -0.62 & 0.44 & $0.81^{*}$ & -0.19 & -0.31 \\
$\mathrm{SO}_{4}^{2-}$ & & & 1 & $0.75^{*}$ & -0.51 & -0.06 & -0.29 & -0.25 & -0.20 \\
$\mathrm{Na}^{+}$ & & & 1 & 0.06 & 0.03 & -0.43 & -0.35 & -0.25 \\
$\mathrm{~K}^{+}$ & & & & 1 & -0.42 & -0.56 & 0.46 & 0.52 \\
$\mathrm{Ca}^{2+}$ & & & & & & 1 & $0.87^{*}$ & -0.94 & -0.96 \\
$\mathrm{Mg}^{2+}$ & & & & & & & -0.69 & -0.77 \\
$\mathrm{Zn}$ & & & & & & & & & $0.99^{*}$ \\
$\mathrm{Fe}$ & & & & & & & & & \\
\hline
\end{tabular}

${ }^{\star}$ Correlation is significant at $\mathrm{p}<0.01$ (two-tailed $\mathrm{t}$-test) 
Table 4. Percent source contributions of ionic species of hailstone in Dhaka, Bangladesh.

\begin{tabular}{cccc}
\hline Ion & Sea salt fraction (\%) & $\begin{array}{c}\text { Terrestrial fraction } \\
\text { Crust fraction (\%) }\end{array}$ & $\begin{array}{c}\text { Anthropogenic } \\
\text { source fraction (\%) }\end{array}$ \\
\hline $\mathrm{K}^{+}$ & 29.1 & 70.9 & - \\
$\mathrm{Ca}^{2+}$ & 0.80 & 99.2 & - \\
$\mathrm{Mg}^{2+}$ & 5.0 & 95.0 & - \\
$\mathrm{NO}_{3}^{-}$ & - & 0.77 & 99.23 \\
$\mathrm{Cl}^{-}$ & 54.20 & 0.42 & 45.38 \\
$\mathrm{SO}_{4}^{2-}$ & 7.31 & 1.83 & 90.86 \\
\hline
\end{tabular}

Crustal fraction dominated for $\mathrm{Ca}^{2+}(99.2 \%)$ and $\mathrm{Mg}^{2+}$ (95.0\%) in hailstone. Similar observations have been made of calcium and magnesium in dew water sample in a previous study in Bangladesh [11]. $\mathrm{Ca}^{2+}$ and $\mathrm{Mg}^{2+}$ could be obtained from the dissolution of both primary and secondary minerals $\left(\mathrm{CaCO}_{3}\right.$, Ca$\mathrm{CO}_{3} \cdot \mathrm{MgCO}_{3}$, and $\mathrm{CaSO}_{4} \cdot 2 \mathrm{H}_{2} \mathrm{O}$ ) commonly present in aerosol particles [31]. Coarse fraction of potassium can be coming from soil but fine particles are due to biomass burning, coal combustion and wood burning [21]. For this reason $\mathrm{K}^{+}$ was considered as terrestrial source because it is hard to distinguish between soil and anthropogenic fraction in hailstone samples [22]. $\mathrm{Cl}^{-}$mainly originated from marine (54.2\%) and a portion from anthropogenic sources (45.4\%). About 99.23\% and $90.26 \% \mathrm{NO}_{3}^{-}$and $\mathrm{SO}_{4}^{2-}$ were attributed to the anthropogenic source. Extensive $\mathrm{NO}_{\mathrm{x}}$ and $\mathrm{SO}_{2}$ released into the environment because vehicles led to the acidic ions ( $\mathrm{NO}_{3}^{-}$and $\mathrm{SO}_{4}^{2-}$ ) in a large extent [29].

\section{Conclusion}

Ionic and some elemental composition of Hailstone samples in Dhaka city were analyzed in the present study. The average value of $\mathrm{pH}$ was 6.95 , which was almost neutral. Average TDS value was $17.5 \mathrm{mg} \cdot \mathrm{L}^{-1}$ revealed that hailstone contained very less dissolved solids. Average sodium adsorption ratio (SAR) was $0.20 \pm 0.09 \mathrm{meq} \cdot \mathrm{L}^{-1}$, indicates that it is suitable for irrigation. $\mathrm{Ca}^{2+}$ had the highest concentrations $\left(163.42 \pm 81.9 \mu \mathrm{eq} \cdot \mathrm{L}^{-1}\right)$ which acted as a significant neutralization factor in hailstone samples. Enrichment factor analysis revealed that $\mathrm{Cl}^{-}$, $\mathrm{NO}_{3}^{-}, \mathrm{SO}_{4}^{2-}$ were mainly from anthropogenic source and $\mathrm{Ca}^{2+}, \mathrm{Mg}^{2+}$ and $\mathrm{K}^{+}$ were from Crustal source. Source contribution analysis further confirmed that anthropogenic activities are the dominant source of $\mathrm{NO}_{3}^{-}$and $\mathrm{SO}_{4}^{2-}$, while $\mathrm{Ca}^{2+}$ and $\mathrm{Mg}^{2+}$ were from crustal source.

\section{Acknowledgements}

The authors would like to acknowledge the Centre for Advanced Research in Sciences (CARS) for helping with chemical analysis. We are grateful to the referees for conferring their constructive implication to upgrade the excellence of this paper. 


\section{Conflicts of Interest}

The authors declare no conflicts of interest regarding the publication of this paper.

\section{References}

[1] Santoyo, E., Garcia, R., Frias, J., Lopez-Vera, F. and Verma, S.P. (2002) Capillary Electrophoretic Analysis of Inorganic Anions in Atmospheric Hailstone Samples. Journal of Chromatography $A, 956,279-286$. https://doi.org/10.1016/S0021-9673(02)00067-5

[2] Trefalt, S., Martynov, A., Barras, H., Besic, N., Hering, A.M., Lenggenhager, S., Noti, P., Rothlisberger, M., Schemm, H., Germann, U. and Martius, O. (2018) A Severe Hail Storm in Complex Topography in Switzerland-Observations and Processes. Atmospheric Research, 209, 76-94. https://doi.org/10.1016/j.atmosres.2018.03.007

[3] Stržinar, G. and Skok, G. (2018) Comparison and Optimization of Radar-Based Hail Detection Algorithms in Slovenia. Atmospheric Research, 203, 275-285.

https://doi.org/10.1016/j.atmosres.2018.01.005

[4] Hermida, L., Lopez, L., Merino, A., Berthet, C., Garcia-Ortega, E., Sanchez, J.L. and Dessens, J. (2015) Hailfall in Southwest France: Relationship with Precipitation, Trends and Wavelet Analysis. Atmospheric Research, 156, 174-188. https://doi.org/10.1016/j.atmosres.2015.01.005

[5] Sánchez, J.L., Merino, A., Melcón, P., García-Ortega, E., Fernández González, S., Berthet, C. and Dessens, J. (2017) Are Meteorological Conditions Favoring Hail Precipitation Change in Southern Europe? Analysis of the Period 1948-2015. Atmospheric Research, 198, 1-10. https://doi.org/10.1016/j.atmosres.2017.08.003

[6] Tasjarek, M., Brooks, H.E. and Czernecki, B. (2017) Sounding-Derived Parameters Associated with Convective Hazards in Europe. American Meterological Society, 145, 1511-1528. https://doi.org/10.1175/MWR-D-16-0384.1

[7] Puchik, T., Groenemeijer, P., Ryva, D. and Kolar, M. (2015) Proximity Soundings of Severe and Nonsevere Thunderstorms in Central Europe. American Meterological Society, 143, 4805-4821.

[8] Johns, R.H. and Doswell III, C.A. (1992) Severe Local Storms Forecasting. Weather Forecast, 7, 588-612. https://doi.org/10.1175/1520-0434(1992)007<0588:SLSF>2.0.CO;2

[9] Madonna, E., Ginsbourger, D. and Martiu, O. (2018) A Poisson Regression Approach to Model Monthly Hail Occurrence in Northern Switzerland Using LargeScale Environmental Variable. Atmospheric Research, 203, 261-274. https://doi.org/10.1016/j.atmosres.2017.11.024

[10] Punge, H.J. and Kunz, M. (2016) Hail Observations and Hailstorm Characteristics in Europe: A Review. Atmospheric Research, 176-177, 159-184. https://doi.org/10.1016/j.atmosres.2016.02.012

[11] Shohel, M., Simol, H., Reid, E., Reid, J. and Salam, A. (2017) Dew Water Chemical Composition and Source Characterization in the IGP Outflow Location (Coastal Bhola, Bangladesh). Air Quality, Atmosphere and Health, 10, 981-990. https://doi.org/10.1007/s11869-017-0487-7

[12] Demographia (2015) World Urban Areas 11th Annual Edition: 2015.01. www.demographia.com/db-worldua.pdf

[13] Rana, M., Sulaiman, M., Sivertsen, N., Khan, B. and Nasreen, S. (2016) Trends in 
Atmospheric Particulate Matter in Dhaka, Bangladesh, and the Vicinity. Environmental Science and Pollution Research, 23, 17393-17403. https://doi.org/10.1007/s11356-016-6950-4

[14] Salam, A., Bauer, H., Kassin, K., Ullah, S.M. and Puxbaum, H. (2003b) Aerosol Chemical Characteristics of an Island Site in the Bay of Bengal (Bhola-Bangladesh). Journal of Environmental Monitoring, 5, 483-490. https://doi.org/10.1039/b212521h

[15] Afser, T. (2018) Chemical Composition and Source Characterization in Rain Water Collected from Dhaka and Coastal Island Bhola, Bangladesh. Thesis Dissertation, Department of Chemistry, University of Dhaka, Dhaka.

[16] Ahmed, M., Hossain, A., Akther, T., Shohel, M. and Salam, A. (2018) Chemical Composition and Source Identification of Fog Water at an Indo-Gangetic Plain (IGP) Outflow Location (Coastal Bhola Island), Bangladesh. Journal of Environmental Pollution and Management, 1, 104.

http://article.scholarena.co/Chemical-Composition-and-Source-Identification-of-F og-Water-at-an-Indo-Gangetic-Plain-IGP-Outflow-Location-Coastal-Bhola-IslandBangladesh.pdf

[17] Degefie, D.T., El-Madany, T.S., Held, M., Hejkal, J., Hammer, E., Dupont, J.C., Haeffelin, M., Fleischer, E. and Klemm, O. (2015) Fog Chemical Composition and Its Feedback to Fog Water Fluxes, Water Vapor Fluxes, and Microphysical Evolution of Two Events near Paris. Atmospheric Research, 164-165, 328-338. https://doi.org/10.1016/j.atmosres.2015.05.002

[18] Salem, T., Omar, M. and Gammal, H. (2017) Evaluation of Fog and Rain Water Collected at Delta Barrage, Egypt as a New Resource for Irrigated Agriculture. Journal of African Earth Sciences, 135, 34-40. https://doi.org/10.1016/j.jafrearsci.2017.08.012

[19] FAO (1985) Guidelines: Land Evaluation for Irrigated Agriculture. FAO Soils Bulletin 55, FAO, Rome, 290.

[20] Balasubramanian, R., Victor, T. and Chun, N. (2001) Chemical and Statistical Analysis of Precipitation in Singapore. Water, Air, and Soil Pollution, 130, 451-456. https://doi.org/10.1023/A:1013801805621

[21] Cao, Y.Z., Wang, S., Zhang, G., Luo, J. and Lu, S. (2009) Chemical Characteristics of Wet Precipitation at an Urban Site of Guangzhou, South China. Atmospheric Research, 94, 462-469. https://doi.org/10.1016/j.atmosres.2009.07.004

[22] Yadav, S. and Kumar, P. (2014) Pollutant Scavenging in Dew Water Collected from an Urban Environment and Related Implications. Air Quality, Atmosphere and Health, 7, 559-566. https://doi.org/10.1007/s11869-014-0258-7

[23] Zhang, M., Wang, S., Wu, F., Yuan, X. and Zhang, Y. (2007) Chemical Composition of Wet Precipitation and Anthropogenic Influence at a Developing Urban Site in Southeastern China. Atmospheric Research, 84, 311-322. https://doi.org/10.1016/j.atmosres.2006.09.003

[24] Shohel, M., Kistler, M., Rahman, M.A., Kasper-Giebl, A., Reid, J.S. and Salam, A. (2018) Chemical Characterization of $\mathrm{PM}_{2.5}$ Collected from a Rural Coastal Island of the Bay of Bengal (Bhola, Bangladesh). Environmetal Science and Polluttion Research, 25, 4558-4569. https://doi.org/10.1007/s11356-017-0695-6

[25] Kidron, G.J. and Starinsky, A. (2012) Chemical Composition of Dew and Rain in an Extreme Desert (Negev): Cobbles Serve as Sink for Nutrients. Journal of Hydrology, 420-421, 284-291. https://doi.org/10.1016/j.jhydrol.2011.12.014

[26] Taylor, S.R. (1964) Abundance of Chemical Elements in the Continental Crust: A 
New Table. Geochimicaet Cosmochimica Acta, 28, 1273-1285.

[27] Safai, P.D., Rao, P.S.P., Momin, G.A., Ali, K., Chate, D.M. and Praveen, P.S. (2004) Chemical Composition of Precipitation during 1984-2002 at Pune, India. Atmospheric Environment, 38, 1705-1714. https://doi.org/10.1016/j.atmosenv.2003.12.016

[28] Shah, M.H. and Shaheen, N. (2010) Seasonal Behaviors in Elemental Composition of Atmospheric Aerosols Collected in Islamabad, Pakistan. Atmospheric Research, 95, 210-223. https://doi.org/10.1016/j.atmosres.2009.10.001

[29] Balakrishna, G. and Pervez, S. (2009) Source Apportionment of Atmospheric Dust Fallout in an Urban-Industrial Environment in India. Aerosol and Air Quality Research, 9, 359-367. https://doi.org/10.4209/aaqr.2008.12.0065

[30] Lu, X., Li, L.Y., Li, N., Yang, G., Luo, D. and Chen, J. (2011) Chemical Characteristics of Spring Rainwater of Xi'an City, NW China. Atmospheric Environment, 45, 5058-5063. https://doi.org/10.1016/j.atmosenv.2011.06.026

[31] Yadav, S. and Rajamani, V. (2006) Air Quality and Trace Metal Chemistry of Different Size Fractions of Aerosols in N-NW India-Implications for Source Diversity. Atmospheric Environment, 40, 698-712. https://doi.org/10.1016/j.atmosenv.2005.10.005

[32] Akter, F. (2018) Water Soluble Ions and Trace Metals Concentrations and Sources Characterization in Fog Water Collected from Coastal Area, Bhola, Bangladesh. Thesis Dissertation, University of Dhaka, Dhaka. 